\title{
Laboratory Simulation of Solar Dryer for Tropical Woods: The Case of Ebony (Diospyros Crassiflora)
}

\author{
Merlin Simo Tagne* \\ Douala Higher Institute of Technology, Douala, Cameroon, PO Box 1623
}

\begin{abstract}
In the present paper, a numerical modeling of solar dryer is doing. This solar dryer operates in the natural convection condition and his construction is not difficult because, local materials are used and it is not necessary to follow a particular formation. We have obtained a numerical solution which explains experimental solution. Application is doing on ebony wood that is a wood most difficult to dry and most utilized for the sculpture. With 30mm of thickness, the sample passed 25 days to reduce his water content to $15 \%$, initial water content was equal to $27 \%$, and the drying period is the month of March from the town of Yaoundé, political capital of Cameroon. This modeling proposed is a modest contribution to explain the solar drying of tropical woods at the laboratory scale.
\end{abstract}

Keywords: Tropical woods, solar drying, modeling, numerical simulation, experiment, diospyros crassiflora.

\section{Introduction}

Solar energy is much used in South and North Africa regions for to dry biologic products for many reasons: this energy is free and his flux is important. This energy is also clean, consequently, development and promotion of solar energy is an alternative solution to optimize fossil energy and to satisfy imperative need of many populations. In the literature, many applications of the solar energy are explained in order to reduce poverty and global climate changes [1,2,3]. Before utilization of wood, the drying permits to reduce water content in order to stabilize a plank of wood. Specialists recommend using a drying table of each wood type. But only, the drying process is good when after, we obtained a good quality of wood, a small consummation of energy during the process, a small damage of atmosphere for a small drying time. In these reasons, it is much important to construct the dryers which satisfied these three conditions quoted above. The dryers of food products are various, because a much studies are detailed in the literature $[4,5,6]$. Some hybrids solar dryers or not are showed in the literature [7]. Formation and technical assistance

${ }^{*}$ Corresponding author. Tel.: +237 94852402

E-mail: simotagne2002@yahoo.fr

(c) 2015 International Association for Sharing Knowledge and Sustainability

DOI: $10.5383 /$ ijtee.09.01.001 are important when we want to ameliorate the drying in these dryers. Numerical simulation to predict experimental values is a good tool to calculate the dimensions of all component of the dryer in order to obtain a precise efficacy. In this paper, we modeling and simulated the functioning of a simple wood indirect solar dryer. The similarity studies are doing in the literature on the expensive dryers which use solar captors $[8,9,10]$ or with the glazed walls $[11,12]$. Application are doing on ebony wood (Diospyros crassiflora) coming from forest of the South-Cameroon region.

\section{Experimental Protocol}

Two samples of ebony wood are used with initial dimension $20 \times 12 \times 3 \mathrm{~cm}^{3}$. The samples are dressed between the plinth and the floor. We have used numerical scales of Sartorus mark in the model BL12. The capacity and the precision of the scales are respectively $12 \mathrm{~kg}$ and $0.1 \mathrm{~g}$. This scales permits to obtain mass evolution wood sample during the process. Relative humidity and drying air temperature are obtained with thermohygrometer of the mark HRT100 with the precision is $1 \%$ for relative humidity and $1{ }^{\circ} \mathrm{C}$ for the temperature. 


\section{Solar Dryer Design}

It is a passive solar dryer in the scale of laboratory (figure 1). These components are constitute of one envelop in plastic (polyethylene) which is hanged on the sticks in anhydrous ayous wood because, it is less costly, available and light. The face above is inclined plane with $10^{\circ}$. The plinth is do in sheetmetal to paint in black (black body) permits the air of dryer to keep up the temperature during a night and the other time that the irradiation is not good. The laboratory dryer operates without air recycling. The plastic membrane and the sheetmetal have respectively a thickness equal to $0.35 \mathrm{~mm}$ and $0.5 \mathrm{~mm}$.

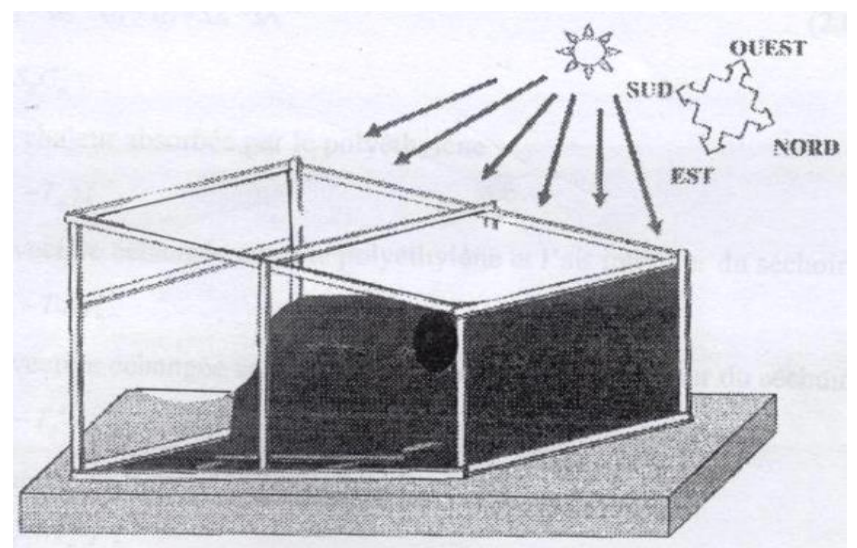

a) Position of the dryer during the drying

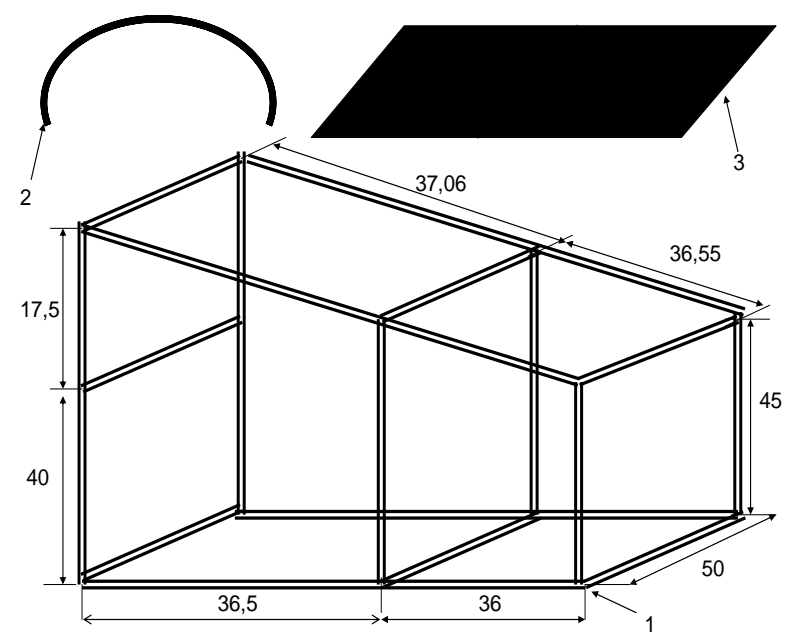

b) Dimension of the dryer in the scale of laboratory

Fig.1. Experimental solar dryer (Dimension in centimeter unit) Indications: 1) wall, 2) plinth, 3) floor

\section{Modeling}

The modeling of a unit of wood solar dryer is most complex for many reasons:

- solar irradiation is function of the site and is non constant during a day;
- the wood to dry is hygroscopic;

- a heat loss in the dryer unit and initial conditions of components of the dryer are always unknown;

- In our modeling, we have used a following simplified hypothesis:

- hygrometry of ambient air out of dryer is supposed monthly constant;

- thermal mutual exchanges between the walls of dryer are neglected;

- temperature and humidity of the samples and the others components of the dryer are uniform in each time.

\subsection{Equations of the model}

-Heat transfer on the wall:

$$
\begin{aligned}
& m_{p} C_{p} \frac{d T_{p}}{d t}=S_{p} G_{t} \alpha_{p}+S_{p} \sigma_{s} F_{p t o}\left(T_{t o}{ }^{4}-T_{p}{ }^{4}\right)-S_{p} h_{c i}\left(T_{p}-T_{a}\right)- \\
& S_{p} \sigma_{s} \varepsilon_{p}\left(T_{p}{ }^{4}-T_{\text {ciel }}{ }^{4}\right)-S_{p} h_{v v}\left(T_{p}-T_{a b}\right)
\end{aligned}
$$

- Heat transfer on the sheet-metal (black body):

$m_{t o} C_{t o} \frac{d T_{t o}}{d t}=S_{t o} G_{t} \alpha_{t o} \tau_{p}-S_{t o} \sigma_{s} F_{t o p}\left(T_{t o}^{4}-T_{p}^{4}\right)-S_{t o} h_{t o}\left(T_{t o}-T_{a}\right)-$

$S_{t o} \sigma_{s} F_{t o b}\left(T_{t o}^{4}-T_{b}^{4}\right)$

- Heat transfer on the drying air:

$\ddot{m}_{a} C_{a}\left(T_{a s}-T_{a e}\right)=-S_{p} h_{c i}\left(T_{a}-T_{p}\right)-S_{b} h_{b}\left(T_{a}-T_{b}\right)-S_{t o} h_{t o}\left(T_{a}-T_{t o}\right)-$

$m_{o}(1-\varepsilon)\left(L_{h e}+E_{b}\right) N$

- Heat transfer on the wood:

$m_{b} C_{b} \frac{d T_{b}}{d t}=-S_{b} F_{b t o} \sigma_{s}\left(\boldsymbol{T}_{b}^{4}-\boldsymbol{T}_{t o}^{4}\right)-S_{b} h_{b}\left(T_{b}-T_{a}\right)-$

$\lambda_{b} S_{b} \frac{d T_{b}}{d x}+m_{o}(1-\varepsilon)\left(L_{h e}+E_{b}\right) N$

-Mass transfer on the wood [13]:

$\frac{d X}{d t}=-N(1-\varepsilon)$

$N(X)=\frac{n\left(X-X_{e q}\right)^{2}}{\sigma\left(X_{o}-X_{e q}\right)}\left(\frac{X_{o}-X}{X-X_{e q}}\right)^{\frac{n-1}{n}}$

- Mass transfer on the air drying [11,12]:

$\rho_{a} V_{s} \frac{d Y_{a}}{d t}+\rho_{o} V_{o} \frac{d X}{d t}+{ }^{*} m_{a}\left(Y_{a}-Y_{a e}\right)=0$

-Temperature of the vault of heaven [14]:

$T_{\text {ciel }}=0.0552 T_{a b}{ }^{1.5}$

-Relative humidity of the air drying [15]:

$H R=\frac{P_{a}}{P_{v s a t}} \frac{Y a}{0.622+Y a}$ 


\subsection{Convective thermal exchange coefficients}

-Between ambient air and the exterior of wall of the dryer Mc Adams relation [14] has been used. It is given by:

$h_{v v}=5.67+3.86 V_{v}$

- Between drying air and the interior wall of the dryer

The Nusselt's number is used [16] and is given by:

$N u=0.27(G r \cdot \operatorname{Pr})^{0.25}$

$h_{c i}=\frac{\lambda N u}{L}$

-Between drying air and sheet-metal (black body)

The Nusselt's number used on each face is given below where hydraulic diameter is the radius [16].

$N u=0.480(G r \cdot \operatorname{Pr})^{0.25}$

$h_{t o}=\frac{N u \lambda}{R}$

-Between drying air and the samples

The Nusselt's number is given by the formula [16]:

$N u=0.54(G r \cdot \operatorname{Pr})^{0.25}$

$h_{b}=\frac{\lambda N u}{L_{b}}$

\subsection{Method of the resolution of the equations of transfer}

Numerical method that we have used is implicit finite differences because all unknown parameters are given in the time $t+\Delta t$. For example, variation of wood water content is given by the relation (17) who comes from relation (5).

$\Delta X=-N(1-\varepsilon) \Delta t$

\section{Results and Discussion}

Characteristics of wood are given in the literature [13]. Experiments are doing during the month of March in the town of Yaoundé-Cameroon (Latitude: $3.87^{\circ} \mathrm{N}$; Longitude: $11.52^{\circ} \mathrm{E}$; Altitude: $720 \mathrm{~m}$ [17]). For this month, literature indicates that irradiation density average is $\mathrm{G}_{\mathrm{t}}=215 \mathrm{~W} / \mathrm{m}^{2}$ [18].

We note a same evolution between theoretical and experimental values. Drying time is $600 \mathrm{~h}$ to pass water content of our wood at $27 \%$ to $17 \%$ (fig.2-a). This drying time is important compared at the time used in artificial drying to obtain same final water content. Difference between experimental and theoretical values (absolute error) is evaluated at $\pm 6.03 \%$. Many reasons can to explain this disagreement. We can note a difficulty to determine with exactitude initial conditions of wood samples and the components of the dryer, a bad estimation of the solar irradiation of the site because, this last value is function of the hour and the day. Also, estimation of the values of modified quasi stationary model that varied with water content. During all manipulations, a door of dryer is opened for to take measures and consequently, exchange between exterior and interior air are doing. In the modeling, this behavior is not taking account. In whole, average differences that we obtained and same evolution between theoretical and experiment, our modeling can to be used for to analyze a behavior of components of the dryer. Thus, this modeling can to be used for to research an optimal functioning of the dryer through a study of sensibility of many parameters. Figure 2-b presents wall temperature evolution, sheet-metal temperature and the interior air of the dryer. Average interior air temperature quickly increases that sheet-metal temperature and wood temperature. Thus, interior air is quickly saturated with water vapor in proximity of the sheet-metal and the wood [19]. Initial temperature of the wall is equal at the ground temperature. Initial temperature of interior air and temperature of sheetmetal are taking equal at the average air exterior of the Yaounde town during a month of experiment. We note a quickly evolution during the ten firsts hours of drying. Air temperature is most important during the seventy firsts hours of drying. Thus, a quickly extraction of water in the wood is favourable. A decrease of air temperature after the ten firsts hours of drying coincided with the increase of wood temperature because air absorbs humidity which evaporate of wood [20]. The wood temperature, the air temperature and the sheet-metal temperature have a same limit temperature $\left(34^{\circ} \mathrm{C}\right)$ showed that a stability temperature of the component of dryer is obtained after 150 hours of the drying. The wall temperature is the most weak because it exchanges a heat with the air exterior. Figure 3 shows a good approximation of the evolution of the water content in dry basis of the wood by our model when initial temperature of drying air is taking equal at $24.4^{\circ} \mathrm{C}$, then in proximate of the ground temperature of the town of Yaoundé in the month (March) of the experiment $\left(24^{\circ} \mathrm{C}\right)$ $[17,21,22]$. In these conditions, average relative error between experiment and theoretical values is $\pm 0.812 \%$. This result shows a very importance of initial conditions on all the evolution of the solar dryer. It is primordial to define good initial conditions before simulate a solar dryer. 


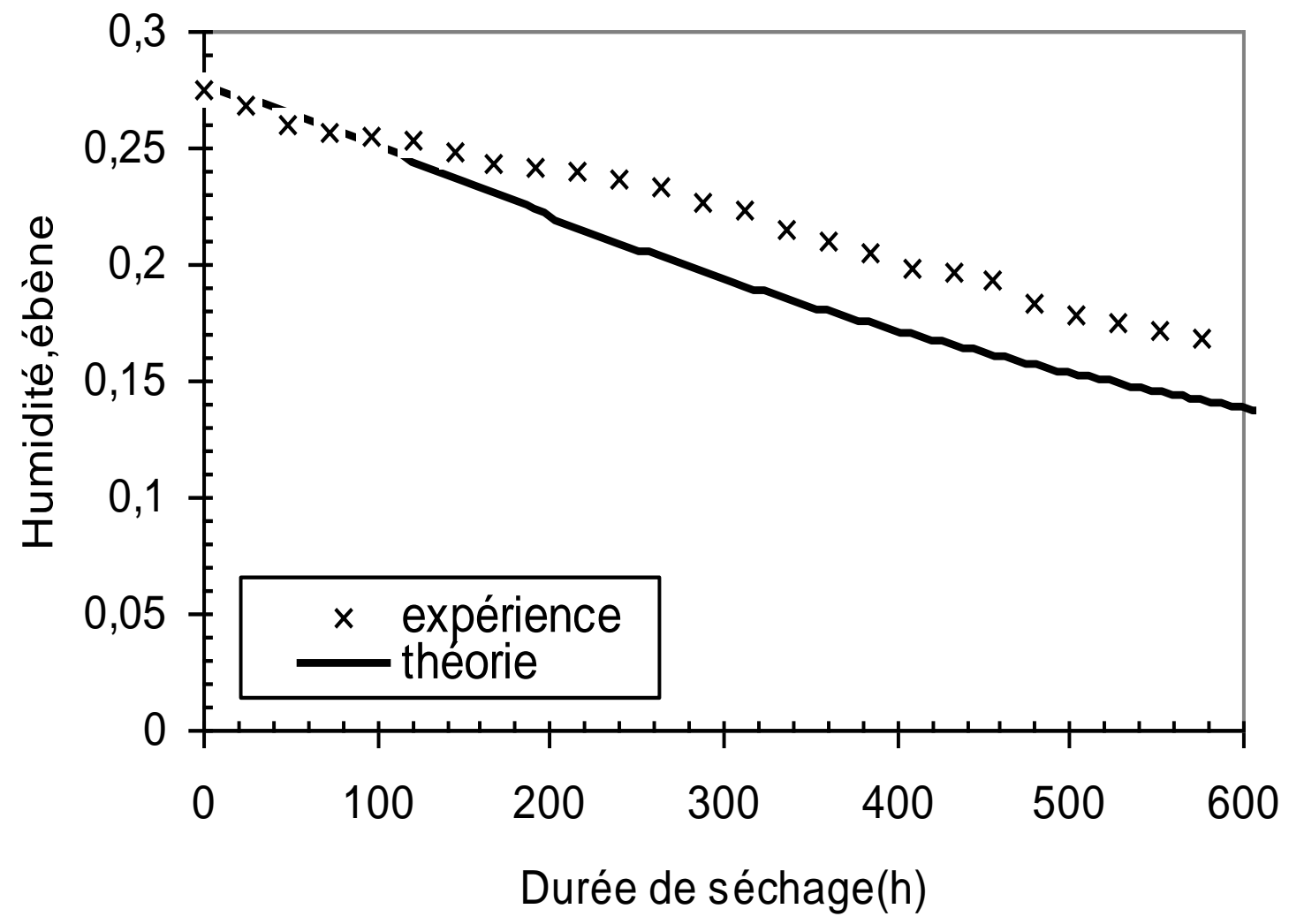

Fig.2.a. Water content $(\mathrm{kg} / \mathrm{kg})$ versus drying time (h)

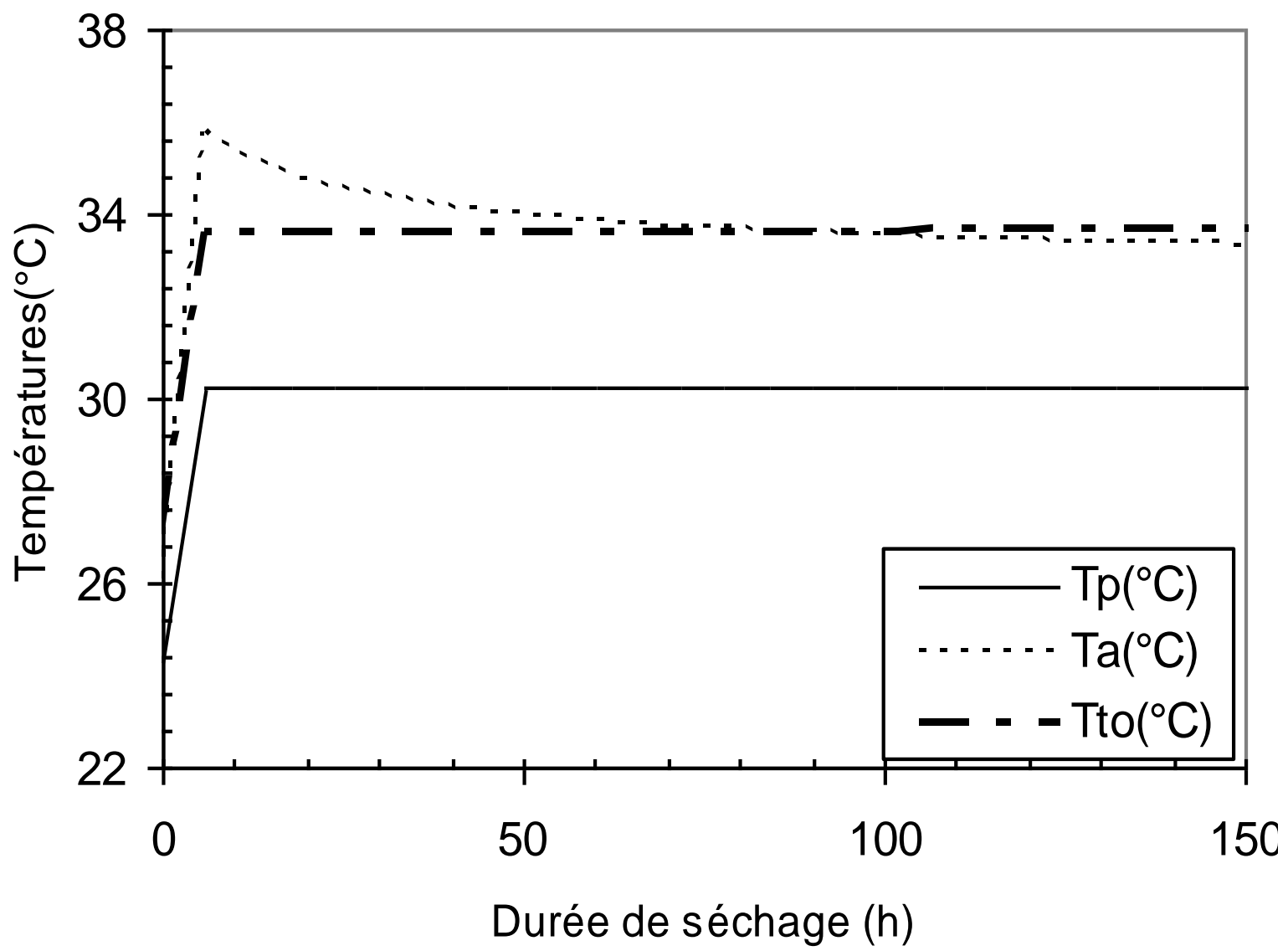

Fig.2.b. Daily average temperature $\left({ }^{\circ} \mathrm{C}\right)$ versus drying time (h) 
Fig.2. Comparative evolutions of theoretical and experimental water content and temperature of the components of the dryer with the drying time

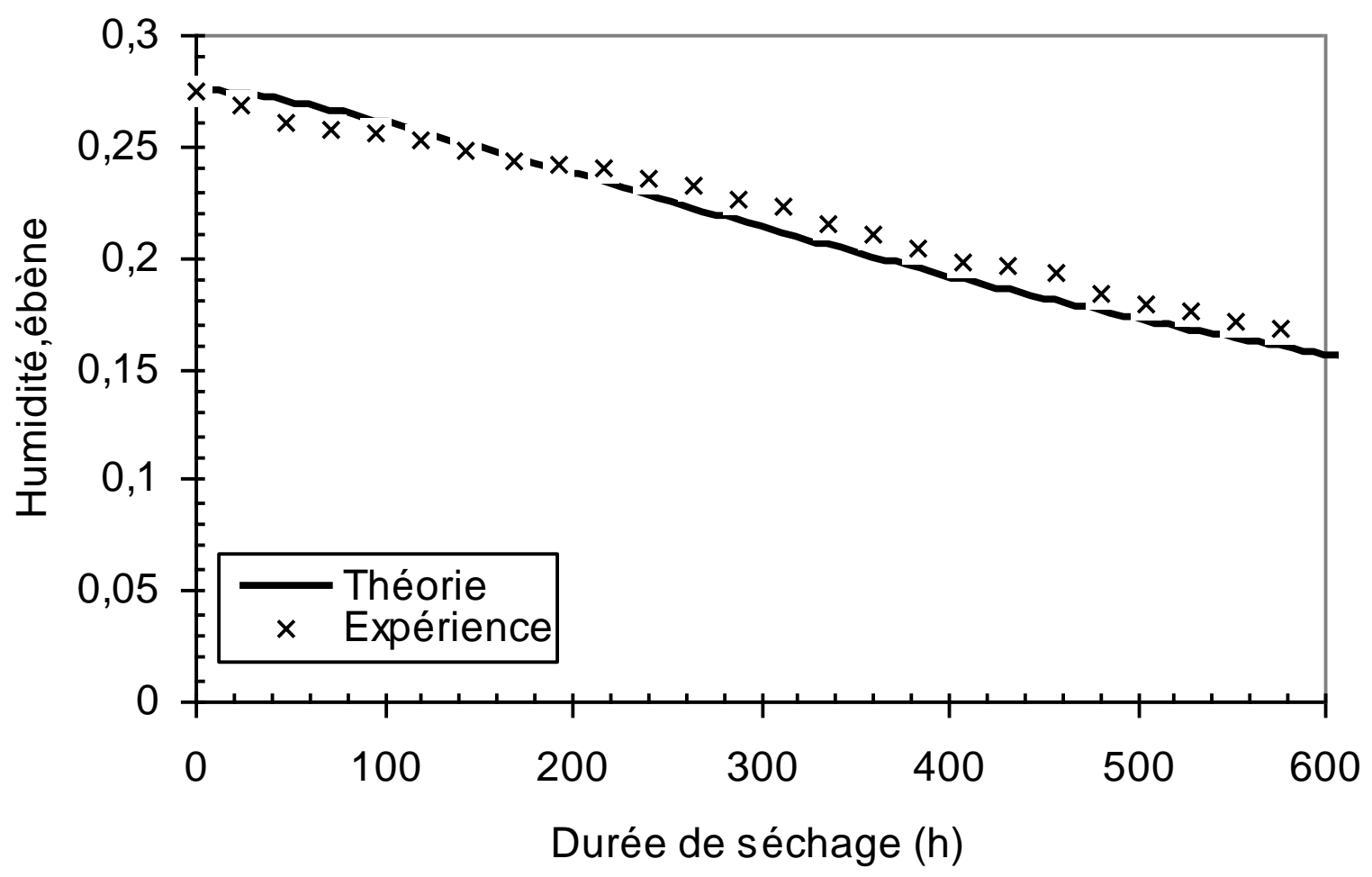

Fig.3. Comparative evolutions of theoretical and experimental water content of the $\operatorname{wood}, T_{a}=24.4^{\circ} \mathrm{C}$

\section{Conclusion}

The present model permits to estimate the evolutions of the temperatures of the components of the solar dryer and also of the water content of wood. A good estimation of initial values of the temperature and humidity of the components of the dryer gives a good estimation of evolutions of these parameters during all the drying process. Final values of the water content are important. For this reason, it is important to envisage a construction of forced convective solar dryer with exchange air between exterior and interior.

\section{Nomenclature}

\section{C: Specific mass heating $(\mathrm{J} /(\mathrm{kg} . \mathrm{K}))$}

$\mathrm{E}_{\mathrm{b}}$ : Heat of desorption of the bound water $(\mathrm{J} / \mathrm{kg})$

$\mathrm{G}_{\mathrm{t}}$ : Solar irradiation $\left(\mathrm{W} / \mathrm{m}^{2}\right)$

HR: Relative humidity of the air (-)

$\mathrm{h}$ :Thermal transfer coefficient $\left(\mathrm{W} /\left(\mathrm{m}^{2} \cdot \mathrm{K}\right)\right)$

L, R: Characteristic diameter (m)

$\mathrm{L}_{\mathrm{he}}$ : Latent heat of vaporization $(\mathrm{J} / \mathrm{kg})$

m: Mass kinetic $(\mathrm{kg} / \mathrm{s})$

m: Mass (kg)

$\mathrm{N}$ : Drying kinetic $(\mathrm{kg} /(\mathrm{kg} . \mathrm{s}))$

$\mathrm{P}$ : Pressure $(\mathrm{Pa})$

S: Surface $\left(\mathrm{m}^{2}\right)$
T: Temperature $\left({ }^{\circ} \mathrm{C}\right)$

$\mathrm{t}$ : Drying time (s)

$\mathrm{V}:$ Volume $\left(\mathrm{m}^{3}\right)$

$\mathrm{V}_{\mathrm{v}}$ : Air kinetic $(\mathrm{m} / \mathrm{s})$

$\mathrm{x}$ : X-axis of the thickness (m)

$X$ : Water content $(\mathrm{kg} / \mathrm{kg})$

Ya: Air humidity $(\mathrm{kg} / \mathrm{kg})$

Greek Symbols

$\alpha$ : Absorptance coefficient(-)

$p$ : Density $\left(\mathrm{kg} / \mathrm{m}^{3}\right)$

$\varepsilon$ : Porosity of the wood (-)

$\varepsilon_{v}$ : Emissivity of the component v (-)

$\lambda$ : Thermal conductivity (W/(kg.K))

$\sigma$ : Second parameter of modified Quasi stationary model (-) $\sigma_{s}:$ Stefan Boltzmann's constant $\left(5.67 \times 10^{-8} \mathrm{~W} /\left(\mathrm{m}^{2} \mathrm{~K}^{4}\right)\right)$

$\tau:$ Transmittance coefficient (-)

Subscripts

a: Air

p: Wall

vsat: Saturated vapor

eq :Equilibrium

$\mathrm{o}$ :Initial or Anhydrous

b, to : (respectively)Wood and black body

$\mathrm{i}, \mathrm{e}:$ (respectively) interior and exterior 
Non-dimensional Numbers

Gr: Grandshopp's number

$\mathrm{Nu}$ : Nusselt's number

n: First parameter of modified Quasi stationary model

Pr : Prandtl's number

\section{Acknowledgments}

I want to thank Pr. Melo born Uphie F. CHINJE, the Director of the Mission of Promotion of the Local Materials (MIPROMALO) of Cameroon for the permission to use the laboratory of her structure.

\section{References}

[1] G. Liu, M. G. Rasul, M. T. O. Amanullah, M. M. K. Khan. Economic and environmental modeling of a photovoltaic- wind-grid hybrid power system in hot arid Australia. Int. J. Thermal \& Environmental Engineering 2010.1:15-22, DOI: 10.5383/ijtee.01.01.003

[2] A. Moussi, G. Asher. Renewable energies: A sustainable future or a prosperous business. Int. J. Thermal \& Environmental Engineering 2010.1: 51-55, DOI: 10.5383/ijtee.01.01.008

[3] S. Ondera, S. Dursunb. Global climate changes and effects on urban climate of urban green spaces. Int. J. Thermal \& Environmental Engineering 2011.1: 37-41, DOI: 10.5383/ijtee.03.01.006

[4] J.O. Ozuomba, N.A. Okonkwo, B.C. Uzor, J.I. Uba. Fabrication and characterization of a direct absorption solar dryer. Advances in Applied Science Research 2013. 4(3):186-194

[5] M.M.V. Ramana.A review of new technologies, models and experimental investigations of solar driers. Renewable and Sustainable Energy Reviews 2009.13: 835-844, DOI: 10.1016/j.rser.2008.02.010

[6] L. Bennamoun, A. Belhamri. Design and simulation of a solar dryer for agriculture products. Journal of Food Engineering 2003.59:259-266. DOI:10.1016/S02608774(02)00466-1

[7] V. Belessiotis, E. Delyannis. Solar drying. Solar Energy 2010. DOI: $10.1016 /$ j.solener.2009.10.001

[8] Khouya A., Draoui A., Tlemçani N. Contribution à l'étude comparative de trois configurations de capteurs solaires plans à air et à application au séchage du bois. $12^{\text {ème }}$ Journées Internationales de Thermique, Tanger-Maroc du 15 au 17 Novembre 2005, 101-104
[9] Khouya A., Benabdelouhab J., Draoui A. Simulation numerique des transferts thermiques dans un système de séchage solaire du bois. $13^{\text {ème }}$ Journées Internationales de Thermique, Albi-France du 28 au 30 Août 2007

[10] Luna-Sanchez D. Modélisation et conception préliminaire d'un séchoir solaire pour bois de pin avec stockage d'énergie. Doctorate Thesis, ENSAM, 10 Juillet 2008

[11] N. Bekkioui, A. Zoulalian, A. Hakam, F. Bentayeb, A. Sesbou. Modelling of a solar wood dryer with glazed walls. Maderas, Cencia y Tecnologia 2009. 11(3):191-205

[12]F. Bentayeb, N. Bekkioui, B. Zeghmati. Modelling and simulation of a wood solar dryer in a Moroccan climate. Renewable Energy 2008. 33: 501-506. DOI: 10.1016/j.renene.2007.03.030

[13] T.M. Simo, B. Bonoma, J.L. Nsouandélé, D. Njomo, B. Ndjidda. Experimental and theoretical study of drying kinetic, of diffusion coefficient and density of ebony. Physical and Chemical News 2010.56:85-91

[14] A. Belghit, M. Belahmidi, A. Bennis, B.C. Boutaleb, S. Benet. Etude numérique d'un séchoir fonctionnant en convection forcée. Revue Générale de Thermique 1997. (36) : 837-850.

[15] Anon. ASHRAE fundamentals handbook :psychrometrics 1989. Chapter 6. Atlanta: American Society of Heating, Refrigerating and Air Conditioning Engineers. 6.1-7.17

[16] Sfeier, A.A. and Guarracino, G : Ingénierie des systèmes solaires. Applications à l'habitat. Technique et Documentation, 1981

[17] D.Afungchui, R.Neba-Ngwa. Global solar radiation of some regions of Cameroon using the linear Angstrom and non-linear polynomial relations (part I) model development. International Journal of Renewable Energy Research 2013. 3(4):984-992

[18] Retscreem International, Natural resources Canada, www.retscreem.net, viewed the 26 may 2009

[19] A. Kuitche, J. Kouam, M. Edoun. Modélisation du profil de température dans un séchoir construit dans un environnement tropical. Journal of Food Engineering 2006. (76) :605-610 DOI :10.1016/j.jfoodeng.2005.06.008

[20]Boubeghal A., Benhammou M., Omari B., Amara S., Amer L., Moungar H., Ouejdi S. Etude numérique d'un séchoir solaire fonctionnant en convection naturelle. Revue des énergies renouvelables, ICRESD-07 Tlemcen 2007. 315-320

[21]N. Djongyang, R. Tchinda, D. Njomo. A study of coupled heat and mass transfer across a porous building component in intertropical conditions. Energy Buildings 2009. DOI: 10.1016/j.enbuild.2008.11.009

[22]A. Kemajou, L. Mba. Matériaux de construction et confort thermique en zone chaude. Application au cas des régions climatiques camerounaises. Revue des Energies Renouvelables 2011. (14)2:239-248 